\title{
Geochemical characteristics of the organic matter in UPPMRs and the implication for fluid-rock exchange due to the retrograde metamorphism in the Dabie-Sulu orogenic belt, North China
}

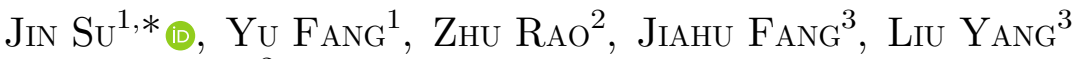 \\ and YI HUANG ${ }^{2}$ \\ ${ }^{1}$ Research Institute of Petroleum Exploration and Development, PetroChina, Beijing 100083 , \\ People's Republic of China. \\ ${ }^{2}$ Chinese Academy of Geological Sciences, Beijing 100 03\%, People's Republic of China. \\ ${ }^{3}$ School of Resources \&3 Safety Engineering, China University of Mining \& Technology, Beijing 100083 , \\ People's Republic of China. \\ ${ }^{*}$ Corresponding author.e-mail: susujinjin@126.com
}

MS received 15 March 2018; revised 26 May 2019; accepted 18 June 2019

The samples were collected from ultrahigh-pressure para-metamorphic rocks (UPPMRs) around 500-2000 m deep by Chinese Continental Scientific Drilling. The combined method of ultrasonic disintegrator and Soxhlet was strictly conducted to extract the indigenous hydrocarbons from the UPPMRs, to obtain non-contaminated and entire organic matter to reveal the geochemical characteristics and origin of hydrocarbons in the UPPMRs. Through gas chromatography-mass spectrometry analysis, the ratios of $\mathrm{Pr} / \mathrm{Ph}$ in the soluble hydrocarbon were from 0.04 to 0.87 . It was inferred that the precursor of extracts would be deposited in the anoxic setting. Based on the relative content among $\mathrm{C}_{27}, \mathrm{C}_{28}$ and $\mathrm{C}_{29}$ steranes, it was found that the main source of organic matter was marine algae. But the isomer ratios of $\mathrm{C}_{31}$ hopane $22 \mathrm{~S} /(22 \mathrm{~S}+22 \mathrm{R})$ were $0.39-0.69$, and the distribution range of $\mathrm{C}_{29}$ sterane $20 \mathrm{~S} /(20 \mathrm{~S}+20 \mathrm{R})$ was $0.41-0.63$, both of which reflected the equivalent maturity of organic matter was no more than $1 \%\left(R_{\mathrm{o}} \%\right)$. Therefore, the immature organic matter derived from algae obviously conflicted with its host rock, which experienced ultrahigh-pressure metamorphism. Therefore, this sort of immature organic matter probably is of secondary origin. Furthermore, the chromatography of $n$-alkane almost assumes bimodal distribution, and the data of $T_{\max }$ ranges from 394 to $565^{\circ} \mathrm{C}$, as $\mathrm{S}_{1} /$ total organic carbon (TOC) ratios systematically increase with the corresponding $T_{\max }$. Therefore, it could be further proved that the organic matter in the UPPMRs probably is of mixed origin and is mainly derived from immigrant hydrocarbons during the stages of subduction and retrograde metamorphism. The emergence of Zr-in-rutile also indicates that the geological temperature was lower than that during the peak of metamorphism. Therefore, it could be inferred that the kerogen associated with rutile might go through diagenesis regularly at the stage of retrograde metamorphism. It was also shown that the $\delta^{18} \mathrm{O}$ value suddenly reduced up to $-10 \%$ o corresponding to the highest TOC $(1820 \mu \mathrm{g} / \mathrm{g})$ around the subduction fault. The relationship between the TOC and $\delta^{18} \mathrm{O}$ value indicated that the fluid-rock exchange reaction was the main reason for the immature organic matter present in the para-metamorphic rock. The returned subduction and retrograde metamorphism resulted in the activity of the formation fluid, which could prominently impact the geochemical characteristics of the para-metamorphic rock and should also be considered in the geodynamics research of the metamorphic orogenic belt.

Published online: 05 September 2019 
Keywords. Ultrahigh-pressure para-metamorphic rock; biomarkers; oxygen isotopes; rutile; retrograde metamorphism; Dabie-Sulu orogenic belt.

\section{Introduction}

Ultrahigh-pressure metamorphism and continental collision orogenesis was always a research hotspot of geodynamics in the latest decades (Coleman and Wang 1995; Liou et al. 2004). New metamorphic mineral assemblage promoted the development of the traditional plate theory. The enormous discovery of coesite and diamond in the metamorphic zones supplied reliable evidence to convince the subduction of crust into mantle (Smith 1984; Chopin 2003). Then the ultrahigh-pressure metamorphism returned and exhumed the shallow crust due to collision orogenesis. Therefore, continental orogenesis usually involved two stages: subduction and exhumation. Numerous research studies have been dedicated to understand the metamorphic mechanism in the process of subduction and exhumation (Hacker and Liou 1998; Carswell and Compagnoni 2003). We could date when the lithosphere started to thicken due to tectonic collision, figure out the formation conditions of metamorphic minerals and reconstruct the thermal history of crustal subduction (Zheng 2008). Fluid activity and material circulation could be other perspectives to explore the geodynamic process.

The main borehole of the Chinese Continental Scientific Drilling (CCSD) is located in the Mesozoic orogeny between the North China and South China plates (figure 1). Previous studies have shown that the peak temperature of metamorphic rocks in the Dabie-Sulu area was up to $850-1000^{\circ} \mathrm{C}$, and the pressure was as high as 3.5-6 GPa (Zheng et al. 2008). As all these parametamorphic rocks originated mostly from a sedimentary precursor and suffered high-temperature metamorphism, the traditional view was that most of the organic matters was completely cracked. Such a high temperature and high pressure had exceeded the traditional 'dead threshold' of organic matter (Tissot and Welte 1984). Polycondensation and graphitisation occurred in the residual organic matter, resulting in graphite being found in granulite facies rocks. However, according to a number of experiments, highcarbon liquid hydrocarbons still exist at a temperature of $700^{\circ} \mathrm{C}$ and a pressure of $3 \mathrm{GPa}$ (Schneider et al. 2006). Therefore, it is still confusing whether the hydrocarbons in ultrahighpressure para-metamorphic rocks (UPPMRs) could inherit or represent the organic composition of the sedimentary precursor. Current geodynamic research is convinced that the subduction unit represents the oceanic crust precursor, and a ductile shear zone, with a thickness of 150-200 m, has been located (Xu et al. 2006). This shear zone supplies a narrow tunnel for the returning and exhumation of the sedimentary precursor and is also associated with complex fluid-rock exchange. But unfortunately, it is unclear as to what sort of fluid activity and organic-inorganic reaction occurred during the subduction and returning process of the para-metamorphic unit.

The stratum of detrital-carbonate experienced an ultrahigh pressure situation with rapid subduction and quick return, and this process only lasted for 10 My (Zhang et al. 2008; Cui et al. 2009; Zeng et al. 2009). The geochemical characteristics of the organic matter in the dynamic metamorphism record the geodynamic process, and this area is the perfectly natural laboratory to observe hydrocarbon behaviour and supply more significant information to explain the geodynamic mechanism of mega orogeny. To reveal the geochemical characteristics of the organic matter in para-metamorphic rocks, 12 samples were collected from the main borehole of CCSD at depths from ca. 500 to ca. $2000 \mathrm{~m}$. The samples involved all varieties of rock types in the entire dynamometamorphic tectonic. The maturity of hydrocarbons in the UPPMRs is discussed using the biomarkers, stable isotopic composition and spectrographic properties of kerogen. The petrography and inclusions of the samples were also used to study the source of hydrocarbons in the para-metamorphic rocks. Based on the research studies on UPPMRs with regard to the geochemical characteristics of organic matter, it would be useful to promote an understanding of the fluid activity during the subduction and returning process of the mega-orogenic tectonic events. This study could possess significant scientific and practical value 


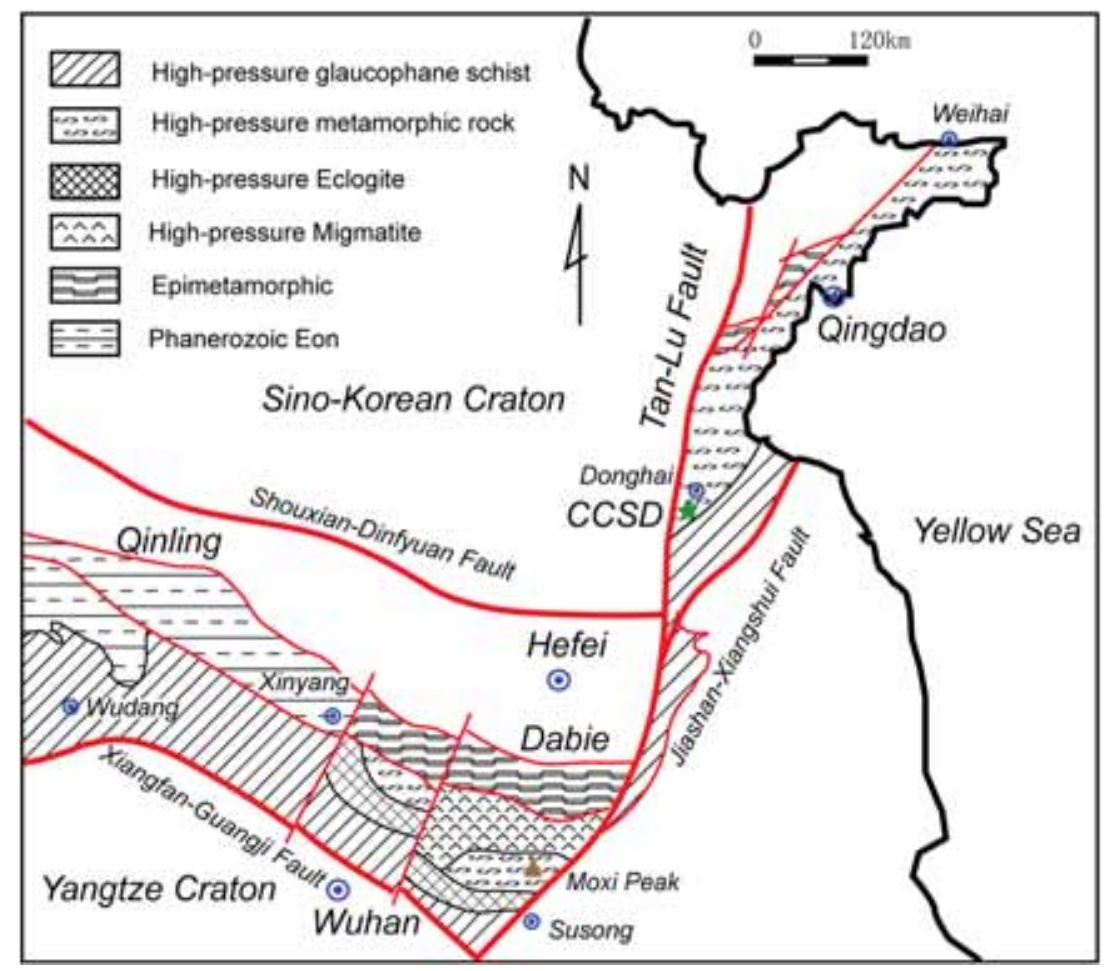

Figure 1. The geographic position of CCSD and the distribution of UPPMRs in the Dabie-Sulu area.

for the research of deep dynamic metamorphism of hydrocarbons.

\section{Geologic setting}

The Dabie-Sulu orogenic belt is one of the most famous ultrahigh-pressure metamorphic zones in the world, due to the collision of the Yangtze and the Sino-Korean craton. The square of this ultrahigh-pressure metamorphic area is $450 \times 75 \mathrm{~km}^{2}$ and detached into two obvious different parts by the NS-trend Tan-Lu fault (figure 1). The Sulu ultrahigh-pressure metamorphic belt (Sulu UPMB) is located east of the northern sector of the Tan-Lu fault, distributed along the NNE-SSW trending (Liu et al. 2009a). The Jiashan-Xiangshui fault is the southern boundary of the Sulu UPMB. The Dabie ultrahigh-pressure metamorphic belt (Dabie UPMB) is situated west of the southern sector of the Tan-Lu fault, coincident with the Qinling mountains (Lou et al. 2009). The relative stratum of the Sulu UPMB and the Dabie UPMB was stricken to the NE direction by $500 \mathrm{~km}$ by the Tan-Lu strike-slip fault (figure 1).

The main borehole of CCSD was drilled in the area of UPPMR south of Donghai city (figure 1). The main drilling hole of CCSD was the epitome of the Sulu UPMB. The 0-2000 m cores in the CCSD mainly consisted of orthogneiss and paragneiss, laminated with thin layers of eclogite, retrogressive eclogite and amphibolite. The precursor of this metamorphic rock was the Palaeozoic flysch sediment (Chen et al. 2009), which experienced greenschist metamorphism and formed high-pressure para-metamorphic rocks (HPPMR). Based on the analysis of mineral composition, it was found that all the UPPMRs might be derived from the metamorphism of mud rocks and retrogressive metamorphism of amphibolite. Based on the geochronological studies of the Sulu UPMB, the ultrahigh- and high-pressure metamorphic events occurred at $\sim 230$ Ma. Meanwhile, the retrograde of hornblende and the overprinting metamorphic of granulite both began at $\sim 210 \mathrm{Ma}$. On combining the measures of $\mathrm{U}-\mathrm{Pb}$ dating in the coesite-bearing domains and quartz-bearing rims of the zircons from the paragneiss, it was revealed that the process of ultrahigh-pressure metamorphism and retrograde occurred at about $227 \pm 2$ Ma (Liu et al. 2008). Based on a recent study of chronology, it was determined that quick subduction movements had occurred twice in the Sulu UPMB. One occurred at 230-213 Ma and another took place at $\sim 195-175 \mathrm{Ma}$ (Liu et al. $2009 \mathrm{~b}$ ). The quick exhumations that occurred twice were associated with the processes of temperatures rising and falling twice (Liu et al. 2009c), and the stratum 
pressure decreasing from 3.5 to $2.8 \mathrm{GPa}$. Thus, this area is the perfectly natural laboratory to investigate the mechanism of deep geodynamics.

\section{Samples}

Twelve samples of UPPMRs from 700 to $2000 \mathrm{~m}$ from the main borehole of the CCSD project were distributed in the lithologic units. At the top was the epidote biotite amphibolite plagioclase gneiss (eclogite gneiss) from 583 to $1130 \mathrm{~m}$ (see sample No. 1-5 in table 1 and figure 2), including multiple layers of kyanite eclogite and amphibolite. The middle unit was the amphibolite biotite plagioclase gneiss and biotite alkali feldspar gneiss from a depth of 1130-1596 m (see sample No. 6-8 in table 1 and figure 2). The third unit was the phengite eclogite, degeneration rutile eclogite including the amphibolite and biotite alkali feldspar gneiss (see sample No. 9-12 in table 1 and figure 2). The lithological type of each sample is exactly presented in table 1 .

In addition, a strong seismic reflector existed at a depth of $1600 \mathrm{~m}$, which was the boundary between the overlying granitic gneiss and the underlying phengite, eclogite and gneiss (see the shear boundary in figure 2). The main trend of the upper strata was $\mathrm{ESE}\left(100^{\circ} \mathrm{E}\right)$, the inclination ranged from $30^{\circ}$ to $40^{\circ}$; but in the lower strata, the main trend was $\operatorname{SSE}\left(160^{\circ} \mathrm{E}\right)$ and the inclination exceeded $50^{\circ}$. At $1600 \mathrm{~m}$ upward, the breccia zone was developed, in which the phenomenon of rounding existed (figure 2), according to which it was presumed that there was a tectonic surface of extension shear between the two strata, which was developed in the late extension stage of the exhumation structure.

\section{Methods}

The powdered sample (ca. 50) was Soxhlet extracted with methanol (MeOH)/dichloromethane (DCM) $(1 / 9 ; \mathrm{v} / \mathrm{v})$ for $72 \mathrm{~h}$. The resulting extracts were separated into fractions using a column $\left(30 \times 0.8 \mathrm{~cm}\right.$, column volume $\left.\left(V_{0}\right)=7 \mathrm{ml}\right)$ packed with silica gel (activated at $120^{\circ} \mathrm{C}$ for $16 \mathrm{~h}$ ) by elution with hexane $(8 \mathrm{ml})$ for the saturated fraction and DCM/hexane $(1: 2, \mathrm{v} / \mathrm{v} ; 10 \mathrm{ml})$ for the aromatic fraction. But, it had not been clear whether this traditional method was suitable to reveal the entire hydrocarbons in the metamorphic rocks. So, the ultrasonic disintegrator was used to extract the hydrocarbons included in the UPPMR. The whole extraction experiment was conducted strictly, including washing the surface of the cores with $\mathrm{H}_{2} \mathrm{O}_{2}$ and cutting the exterior to clean samples. During the procedure of extraction, all of the solvents had been 20 times concentrated to guarantee a blank during extraction.

The difficulty of investigating the organic characteristics of UPPMR was the separation of kerogen from fluoride (Durand 1980; Zhu 1981). Different from the kerogen from sedimentary rocks, the insoluble organic matter of UPPMR contained fluoride, which could not be isolated completely by conventional flotation. Therefore, special flotation fluid ( $\mathrm{ZnCl-KI}$ in acetic acid, $2.06 \mathrm{~g} / \mathrm{cm}^{3}$ ) was used to isolate kerogen. After flotation, the samples were centrifuged for $20 \mathrm{~min}$ at $600 \mathrm{rpm}$.

Table 1. The samples information of Chinese Continent Science Drilling 700-2000 m (Donghai).

\begin{tabular}{rlll}
\hline & No. of samples & \multicolumn{1}{c}{ Depth $(\mathrm{m})$} & \multicolumn{1}{c}{ Main lithology } \\
\hline 1 & B387R304P1a & $735-742$ & Calcite biotite hornblende plagioclase gneiss \\
2 & B425R329P7u & $798-800$ & Pyrite limestone adamellite gneiss \\
3 & B426R329P7z & $801-802$ & Epidotic homblendic schist \\
4 & B442R342P1c & $820.91-832.70$ & Epidotic homblendic biotite plagioclase gneiss \\
5 & B623R439P6a & $1121-1129$ & Epidotic homblendic gneiss \\
6 & B644R458P2c & $1263-1273$ & Epidotic homblendic plagioclase gneiss \\
7 & B819R556P4b & $1564-1571$ & Magnetite felsic gneiss \\
8 & B820R558P2 & $1571-1579$ & Chlorite biotite homblendic schist \\
9 & B952R626P5a & $1828-1837$ & Phengite eclogite \\
10 & B956R627P4a & $1838-1840$ & Homblendic plagioclase gneiss \\
11 & B957R627P4t & $1841.13-1844$ & Epidotic biotite homblendic schist \\
12 & B966R629P3t & $1850-1857$ & Phengite eclogite \\
\hline
\end{tabular}




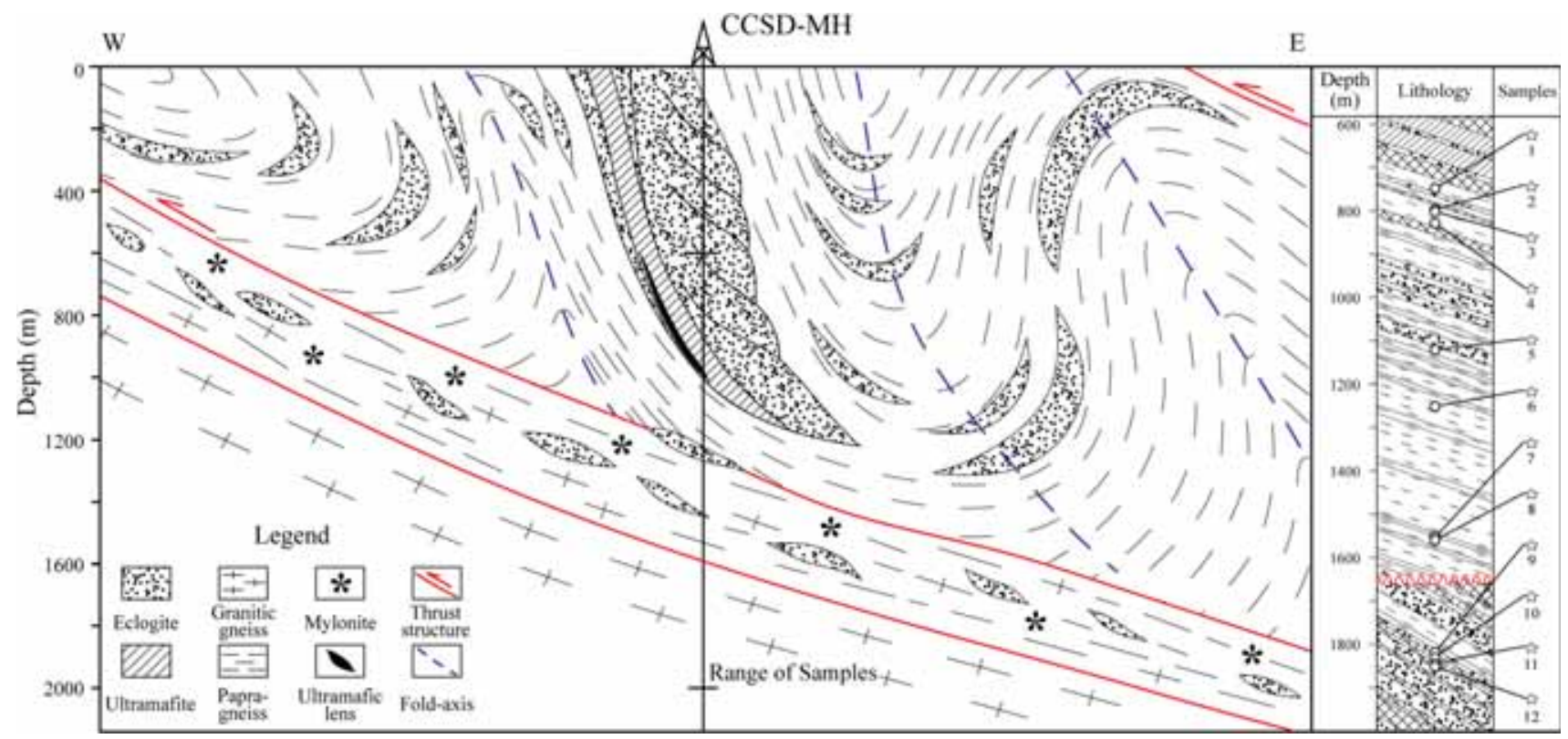

Figure 2. The profile of crustal fold, thrusting structure and ductile shear zone with the lithological composition of UPPMRs cross the CCSD main borehole (after Zheng 2008).

\subsection{Soluble organic matter detected by gas chromatography-mass spectrometry (GC-MS)}

GC-8060/MD-800 equipment was used for GC-MS testing from Finnigan Corporation, USA. The capillary column was ZB-5 (J\&W Co., USA), which was suitable for detection by mass spectrometry. To test all the organic compounds, the scan range of MS was 35.00-550.00 amu. Helium was the carrier gas, with a constant current of $1 \mathrm{~cm}^{3} / \mathrm{min}$. The temperature programme is as follows: a constant temperature of $50^{\circ} \mathrm{C}$ for $5 \mathrm{~min} ; 50-220^{\circ} \mathrm{C}$ with a rate of $4^{\circ} \mathrm{C} / \mathrm{min}$; $220-320^{\circ} \mathrm{C}$ with a rate of $2.0^{\circ} \mathrm{C} / \mathrm{min}$; a constant temperature of $320^{\circ} \mathrm{C}$ for $25 \mathrm{~min}$ and the gasification chamber temperature was $300^{\circ} \mathrm{C}$. An HP-5 capillary column was adopted in the GC with a length of $30 \mathrm{~m}$, a diameter of $0.25 \mathrm{~mm}$ and a film thickness of $0.25 \mu \mathrm{m}$.

\subsection{Detection by Rock-Eval}

The hydrocarbon potential of UPPMR was evaluated using Rock-Eval 2plus (France) at the assessment station of petroleum (RIPED, China). The conditions of instruction are as follows: adsorbed organic matter $\left(\mathrm{S}_{1}\right)$ was tested by heating $3 \mathrm{~min}$ at $300^{\circ} \mathrm{C}$ and bounded organic matter $\left(\mathrm{S}_{2}\right)$ was detected with the temperature rising from $300^{\circ} \mathrm{C}$ to $600^{\circ} \mathrm{C}$ at a heating rate of $50^{\circ} \mathrm{C} / \mathrm{min}$. Then the $\mathrm{S}_{1}$ and $\mathrm{S}_{2}$ were burnt to $\mathrm{CO}_{2}$, which was quantified at $390^{\circ} \mathrm{C}$ in a trap well.

\subsection{Fourier transform infrared (FTIR) spectrum of kerogen}

The mixture of $0.68 \mathrm{mg}$ kerogen and $150 \mathrm{mg} \mathrm{KBr}$ was smashed for $10 \mathrm{~min}$, and then the powered sample was squashed into a round sheet under $10 \mathrm{Mpa}$. FTIR spectroscopy was performed using TFS-113V (Bruker Co., Germany). The analysis conditions of the FTIR spectrum were luminous flux $=15,000, \mathrm{XSP}=4000$ $\mathrm{cm}^{-1}, \mathrm{XEP}=400 \mathrm{~cm}^{-1}, \mathrm{NSS}=16$ and $\mathrm{VEL}=16$.

\subsection{Analysis of the carbon and oxygen isotopes}

The carbon isotope of the prepared pure kerogen was analysed using Thermo Delta V Advantage, an ion source vacuum of 8.6-8.9 $\times 10^{-7}$ mbar and an ion source voltage of $3.07 \mathrm{kV}$. In the temperature programme, the temperature rose from $33^{\circ} \mathrm{C}$ at a rate of $8^{\circ} \mathrm{C} / \mathrm{m}$ to $80^{\circ} \mathrm{C}$ and then rose up to $250^{\circ} \mathrm{C}$ at a rate of $5^{\circ} \mathrm{C} / \mathrm{m}$ for $20 \mathrm{~min}$ of constant temperature.

An aliquot of UPPMR samples (ca. $10 \mathrm{~g}$ ) reacted with $100 \%$ phosphoric acid under vacuum at $50.0 \pm$ $0.1^{\circ} \mathrm{C}$ for $36 \mathrm{~h}$. The collection of the resulting $\mathrm{CO}_{2}$ was analysed for oxygen isotope using a Delta-XP mass spectrometer of continuous flow (Finnigan Co., USA).

\section{Results and discussion}

Based on the Rock-Eval data, the $T_{\max }$ of average UPPMR samples is above $450^{\circ} \mathrm{C}$ (except sample No. 11) (figure 3), which is the commonly equated 


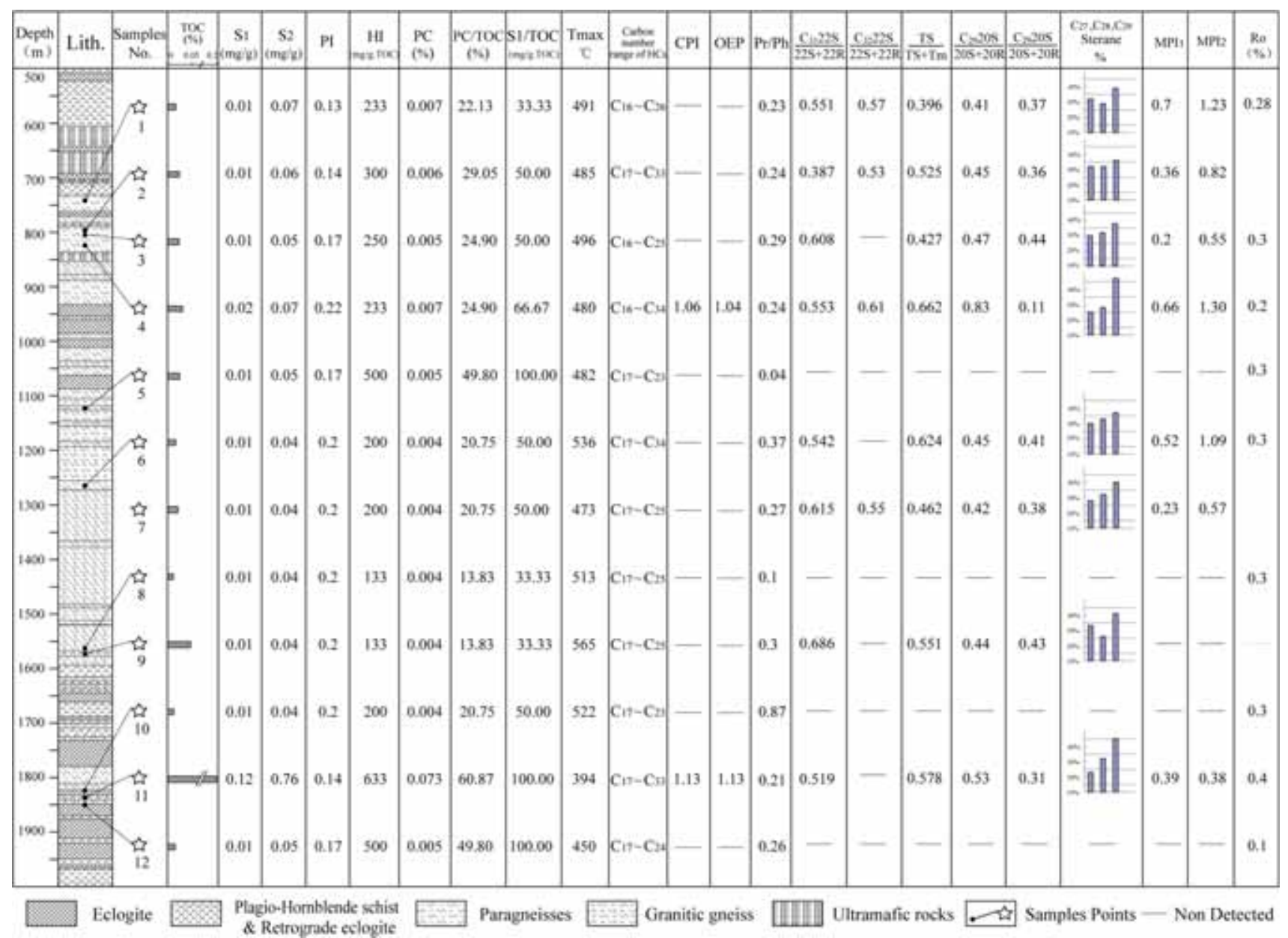

Figure 3. The comparison of maturity, potential content and biomarker characteristics of hydrocarbons in the UPPMR samples detected by Rock-Eval and GC-MS.

high maturity of sedimentary rocks $\left(>\sim 1.2 \% R_{\mathrm{o}}\right)$ consisting of UPPMRs. Meanwhile, the total organic carbon (TOC) in most of the UPPMR samples is quite lower than that of typical TOC in sedimentary rocks, as the majority ranges from 111 to $516 \mu \mathrm{g} / \mathrm{g}$ (except sample No. 11). The production index is $0.13-0.22$ (figure 3 ), which also indicates high maturity. The $\mathrm{S}_{1}$ of almost all samples is $0.01 \mathrm{mg} / \mathrm{g}$, and $\mathrm{S}_{2}$ is abnormally low, ranging from 0.04 to $0.07 \mathrm{mg} / \mathrm{g}$ (figure 3 ), which was initially found to be the residual hydrocarbons in the UPPMRs. However, the $T_{\max }$ of all samples widely spans from $394^{\circ} \mathrm{C}$ to $565^{\circ} \mathrm{C}$. The $T_{\max }$ of the special No. 11 sample was just $394^{\circ} \mathrm{C}$ and quite below the oil-window of sedimentary rocks $\left(T_{\max }=435^{\circ} \mathrm{C}\right)$ (Tissot and Welte 1984) rather than of high maturity. The percentage of pyrolysis hydrocarbons in TOC was from $13.83 \%$ to $60.87 \%$, which implicates that both the thermal evolution of all UPPMR and the maturity of pyrolysis hydrocarbons varied and are not consistent. Especially, the highest TOC appeared in the paragneiss and plagio-hornblende schist (sample No. 11), which was $1820 \mu \mathrm{g} / \mathrm{g}$ at a depth of $1842 \mathrm{~m}$ near the boundary of the shear zone. So, further investigation of the biomarkers in soluble hydrocarbons is needed to figure out whether the organic matter is residual in average UPPMRs.

From the GC-MS analysis, the maturity parameters of isomer biomarkers released that the revolution of soluble organic matter in the UPPMR had not achieved the thermodynamics equilibrium under geological conditions (figure 3 ) such as the ratios of $\mathrm{C}_{32}$ hopane $22 \mathrm{~S} /(22 \mathrm{~S}+22 \mathrm{R})$ were $0.53-0.61$, the ratio of $T_{\mathrm{s}} /\left(T_{\mathrm{s}}+T_{\mathrm{m}}\right)$ was from 0.40 to 0.66 and the ratio of $\mathrm{C}_{29}$ sterane $20 \mathrm{~S} /$ $(20 \mathrm{~S}+20 \mathrm{R})$ was $0.41-0.63$, all of which indicate that the thermal maturity of soluble hydrocarbons was in the oil-window stage (see discussion in section 5.1). The exact reflectivity of analogous vitrinite was only $\sim 0.3 \%$, and the analogous vitrinite reflectivity in the strata below the shear zone was 
only $0.1 \%$ (figure 3 ). Thus, a few parts of organic matter in UPPMR should be secondary rather than residual hydrocarbons. In accordance with the previous thermal simulation, the stability of longchain alkanes was proved under the conditions of high pressure and increased activation energy of the reaction (Price and Wenger 1992), because the ultrahigh-pressure conditions inhibited the reaction of demethylation, aromatisation and dehydrogenation in the maturation process of the organic matter. This might provide some enlightenment for the revolution of the organic matter under the conditions of ultrahigh pressure and temperature. Therefore, the analysis data of samples would be discussed around whether the organic matter in the samples had experienced metamorphism together with UPPMR. The revolutionary mechanism of the organic matter in the UPPMR also needs to be elucidated.

\subsection{Characteristics of the soluble organic matter in the UPPMR}

Regarding the integrity of the soluble organic matter in the UPPMR, the powered sample was extracted using a combination of Soxhlet first and ultrasonic extraction in sequence next. The organic matter in mineral inclusions could be recovered by ultrasonic shattering. As shown, the main peak $n-\mathrm{C}_{20}$ in the chromatography of Soxhlet extraction and the main peak $n$ - $\mathrm{C}_{30}$ in the chromatography of bitumen resulted from the ultrasonic extraction (figure 4). Therefore, the two parts of the soluble organic matter were merged as the entire soluble organic matter.

(a)

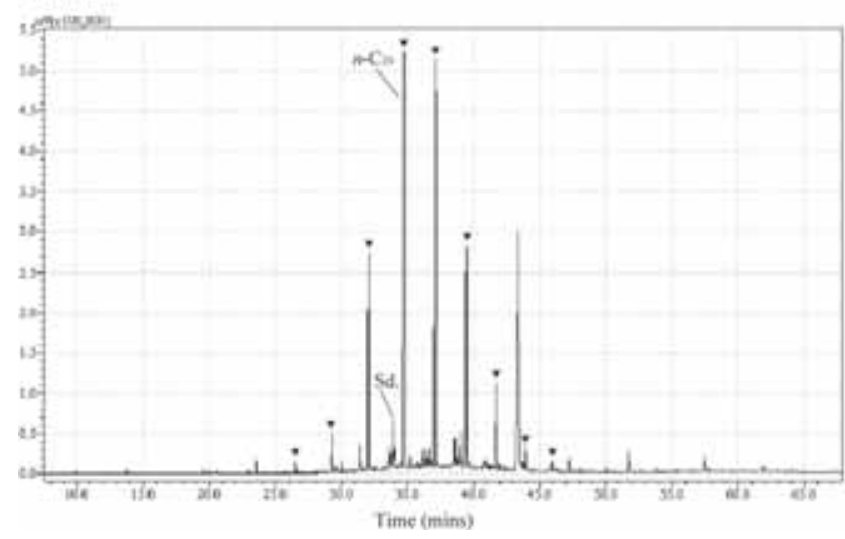

With the GC-MS analysis, the main peak of $n$-alkane ranged from $\mathrm{C}_{20}$ to $\mathrm{C}_{31}$ in the soluble organic matter of 12 samples, and was bimodal (figure 5). From the traditional view of the bimodal pattern, the origin of light $n$-alkanes is from microorganisms, and the heavy $n$-alkanes are from terrigenous plants. But based on the $\mathrm{Pr} / \mathrm{Ph}$ ratio from 0.04 to 0.87 , it was indicated that the organic matter might develop in the anoxic environment. Especially, the concentration of heavy $n$-alkanes is quite lower than that of light $n$-alkanes in most of the samples. Therefore, the contribution of plants is limited. In a previous research, it was revealed that the chromatography of $n$-alkanes derived from subsea Spirulina possessing the bimodal property. When the maturity elevated at $200^{\circ} \mathrm{C}$ during the simulation experiment, the high carbon number disappeared. But at $250^{\circ} \mathrm{C}$, the bimodal property reappeared ( $\mathrm{Li}$ 2002). Therefore, based on the chromatography of $n$-alkanes in sample No. 4 (B442R342P1c), it was concluded that the origin of the organic matter in UPPMR was possible from marine algae. So, further discussion would be necessary to clarify the evolution stage of the organic matter in the UPPMR samples.

With regard to organic maturity, the ratio of $\mathrm{C}_{32}$ hopane $22 \mathrm{~S} /(22 \mathrm{~S}+22 \mathrm{R})$ was $0.53-0.61$, which indicated that the thermal revolution of the organic matter was in the oil-window stage. The range of the $T_{\mathrm{s}} /\left(T_{\mathrm{s}}+T_{\mathrm{m}}\right)$ ratios was from 0.40 to 0.66 (figure 6); all the maturity parameters had not reached equilibrium, which also revealed that the thermal revolution of the organic matter had not reached the stage post maturity. During the thermal maturity process of the organic matter, the biological configuration of biomarkers would transform

(b)

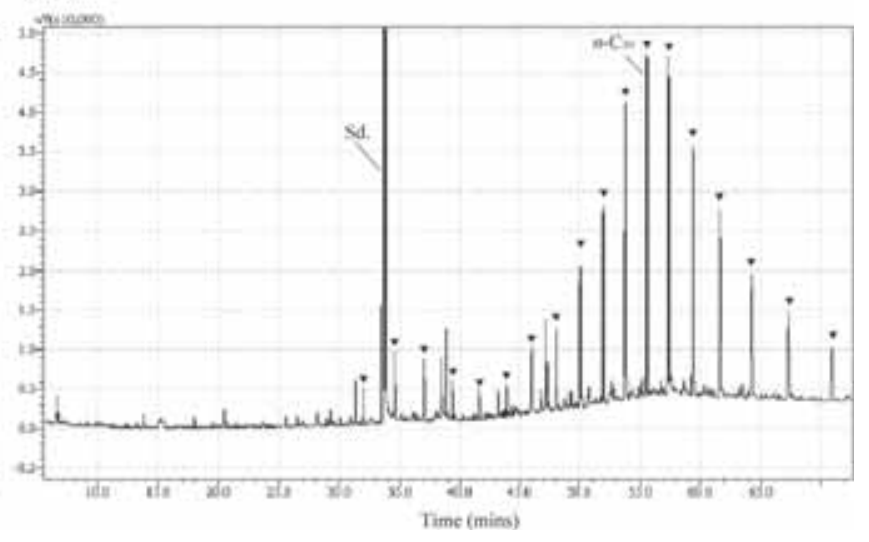

Figure 4. Comparison of gas chromatography disposed by Soxhlet and ultrasonic extraction from sample No. 6 (B644R458P2c). (a) Soxhlet extraction and (b) ultrasonic extraction. 


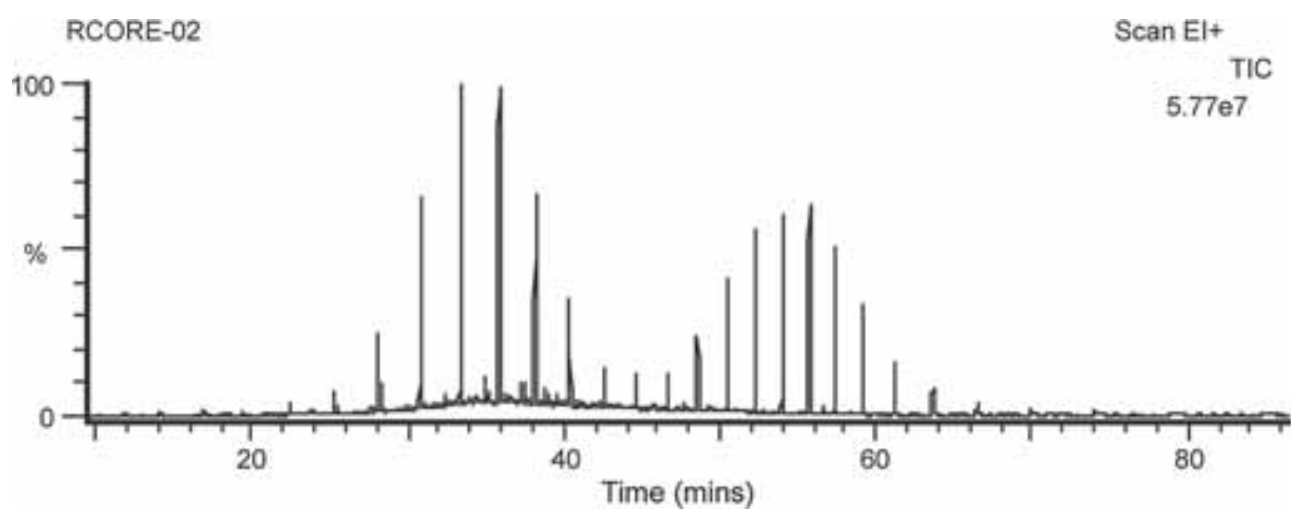

Figure 5. The TIC chart of the saturated hydrocarbon in sample No. 4 (B442R342P1c).

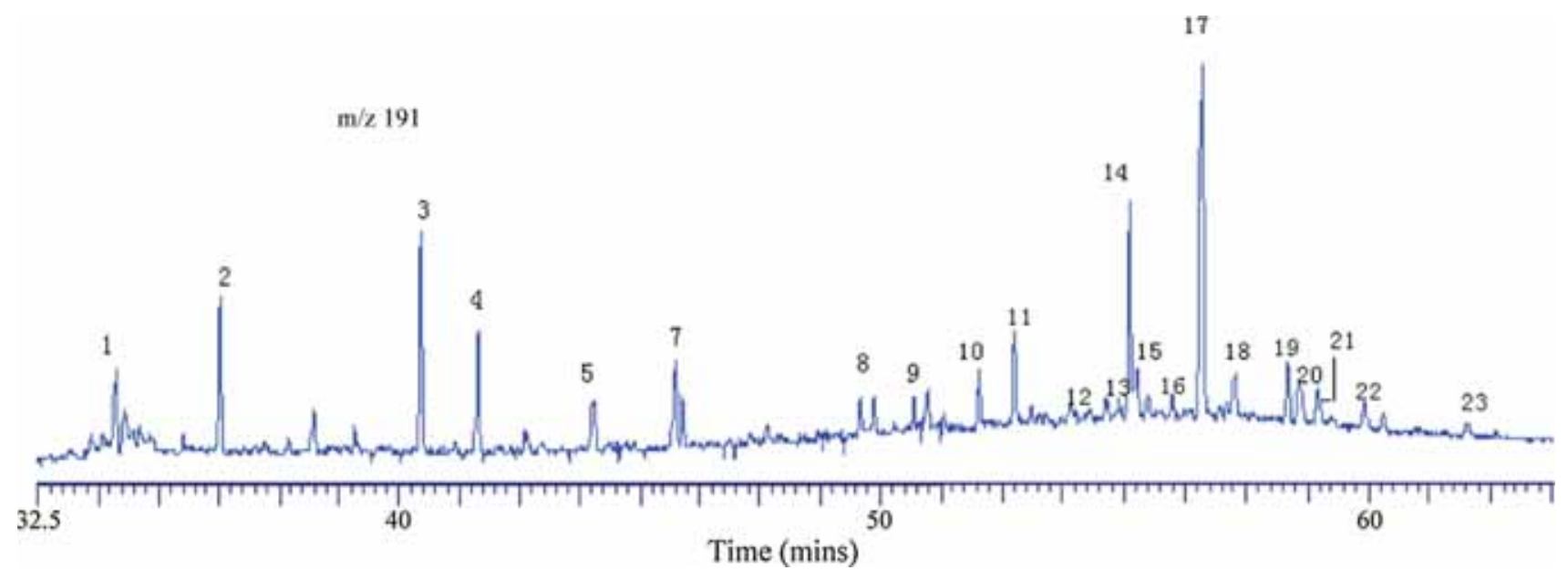

Figure 6. The $m / z 191$ mass chromatogram of sample No. 11 (B957R627P4t). Notes: 1. C 20 Tricyclic Terpane (TT); 2. C 21 TT; 3. $\mathrm{C}_{23}$ TT; 4. $\mathrm{C}_{24}$ TT; 5. C 25 TT; 7. C 26 Tetracyclic Terpane; 8. C 28 TT; 9. $\mathrm{C}_{29}$ TT; 10. 18 $\alpha(\mathrm{H})-22,29,30$-trisnorneohopane (Ts); 11. $17 \alpha(\mathrm{H})-22,29,30$-trisnorneohopane; (Tm); 12. $\mathrm{C}_{29} \mathrm{TT} ; 13 . \mathrm{C}_{30} \mathrm{TT} ; 14.17 \alpha(\mathrm{H}), 21 \beta(\mathrm{H})-30$-norhopane; 15. 18 $\alpha(\mathrm{H})-30-$ norneohopane $\left(\mathrm{C}_{29} \mathrm{Ts}\right) ; 16.17 \alpha(\mathrm{H}), 21 \alpha(\mathrm{H})$-30-norhopane; 17. $17 \alpha(\mathrm{H}), 21 \beta(\mathrm{H})$-hopane; 18. 17 $\beta(\mathrm{H}), 21 \alpha(\mathrm{H})$-hopane; 19. 17 $\alpha(\mathrm{H})$, $21 \beta(\mathrm{H})$-29-homohopane 22S; 20. $17 \alpha(\mathrm{H}), 21 \beta(\mathrm{H})$-29-homohopane 22R; 21. Gammacerane; 22. 17 $\alpha(\mathrm{H}), 21 \beta(\mathrm{H})-29$-bishomohopane 22S; $23.17 \alpha(\mathrm{H}), 21 \beta(\mathrm{H})-29$-trishomohopane $22 \mathrm{~S}$.

into the geological configuration, and the relative concentration of isomers corresponds to a certain maturity point of the organic matter (Zhang and Huang 2005). So, based on the four maturity parameters, it could be concluded that the thermal revolution of the organic matter in the UPPMR was equivalent to the $V R_{\mathrm{o}}^{\mathrm{E}}=0.5-0.9 \%$. It might also be indicated that the organic matter of UPPMR had not experienced ultra-pressure metamorphism.

The distribution range of the $\mathrm{C}_{29}$ sterane $20 \mathrm{~S} /$ $(20 \mathrm{~S}+20 \mathrm{R})$ ratio was from 0.41 to 0.63 and the $\mathrm{C}_{29}$ sterane $\beta \beta /(\alpha \alpha+\beta \beta)$ ratio was $0.31-0.44$. Both of the maturity parameters of steranes were close to the equilibrium of mature evolution, because the epimerisation equilibrium of $\mathrm{S} /$ $(\mathrm{S}+\mathrm{R})$ and $\beta \beta /(\alpha \alpha+\beta \beta)$ was 0.55 and 0.7 , respectively, (Moldowan et al. 1986). The ratio of
$\mathrm{S} /(\mathrm{S}+\mathrm{R})$ in some samples was beyond 0.55 which might have been disturbed by the biodegradation of bacteria (Clegg et al. 1998). Therefore, it can be explained that the organic matter in the UPPMR has secondary origin. As is well known, if the hydrocarbons experienced the metamorphism of ultrahigh pressure and temperature (Wang et al. 2008; Richard et al. 2008), the steranes could not be detected or the abundance would be an order of magnitude less than that in normal sedimentary rocks (figure 7 ). Therefore, the maturity parameters of steranes also reflected the same level of maturity as the parameters of hopanes $\left(R_{\mathrm{o}}=0.6-0.9 \%\right)$.

Referring to the triangular chart of the relative content of $\mathrm{C}_{27}, \mathrm{C}_{28}$ and $\mathrm{C}_{29}$ sterane (figure 8), the source of the organic matter was confirmed as mainly algae (Peters et al. 1994). This conclusion 


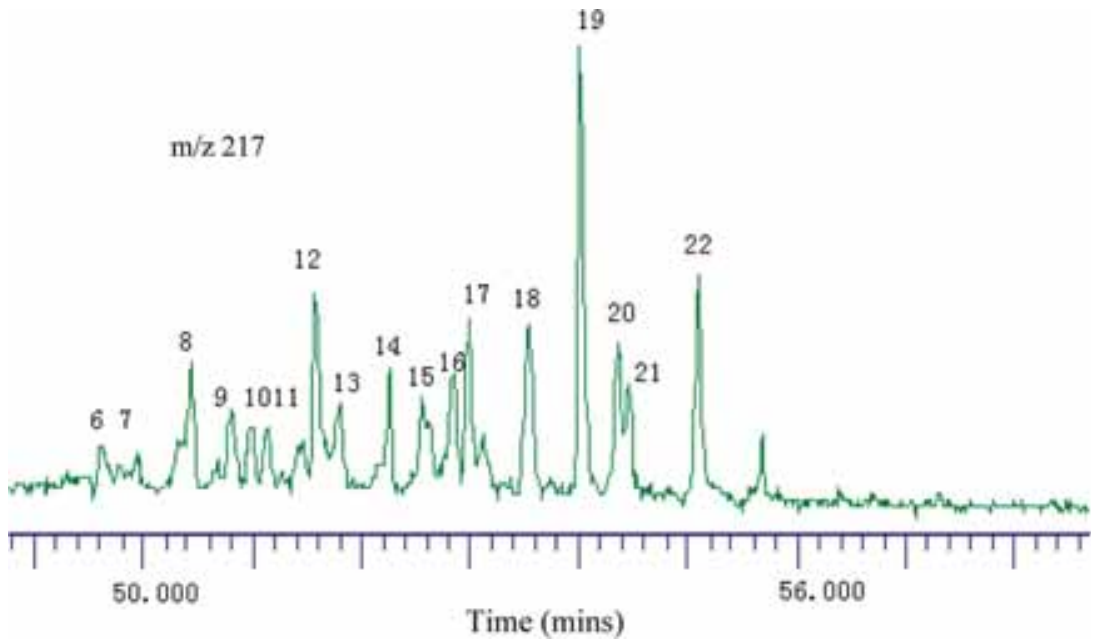

Figure 7. The $m / z 217$ mass chromatogram of sample No. 11 (B957R627P4t). Notes: 8. 13 $\alpha, 17 \beta$-C 28 diasterane 20R $(24 \mathrm{~S}+24 \mathrm{R})$; $9.5 \alpha, 14 \alpha, 17 \alpha-\mathrm{C}_{27}$ sterane $20 \mathrm{R} ; 10.5 \alpha, 14 \beta, 17 \beta-\mathrm{C}_{27}$ sterane $20 \mathrm{~S} ; 11.5 \alpha, 14 \beta, 17 \beta-\mathrm{C}_{27}$ sterane $20 \mathrm{~S} ; 12.5 \alpha, 14 \alpha, 17 \alpha-\mathrm{C}_{27}$ sterane $20 \mathrm{R}$; 13. $13 \alpha, 17 \beta-\mathrm{C}_{29}$ diasterane $20 \mathrm{R} ; 14.13 \alpha, 17 \beta-\mathrm{C}_{29}$ diasterane $20 \mathrm{~S} ; 15.5 \alpha, 14 \alpha, 17 \alpha-\mathrm{C}_{28}$ sterane $20 \mathrm{~S} ; 16.5 \alpha, 14 \beta, 17 \beta$-C 28 sterane $20 \mathrm{R}$; 17. $5 \alpha, 14 \beta, 17 \beta-\mathrm{C}_{28}$ sterane $20 \mathrm{~S} ; 18.5 \alpha, 14 \alpha, 17 \alpha-\mathrm{C}_{28}$ sterane $20 \mathrm{R} ; 19.5 \alpha, 14 \alpha, 17 \alpha-\mathrm{C}_{29}$ sterane $20 \mathrm{~S} ; 20.5 \alpha, 14 \beta, 17 \beta-\mathrm{C}_{29}$ sterane $20 \mathrm{R} ; 21.5 \alpha, 14 \beta, 17 \beta-\mathrm{C}_{29}$ sterane $20 \mathrm{~S} ; 22.5 \alpha, 14 \alpha, 17 \alpha-\mathrm{C}_{29}$ sterane $20 \mathrm{R}$.

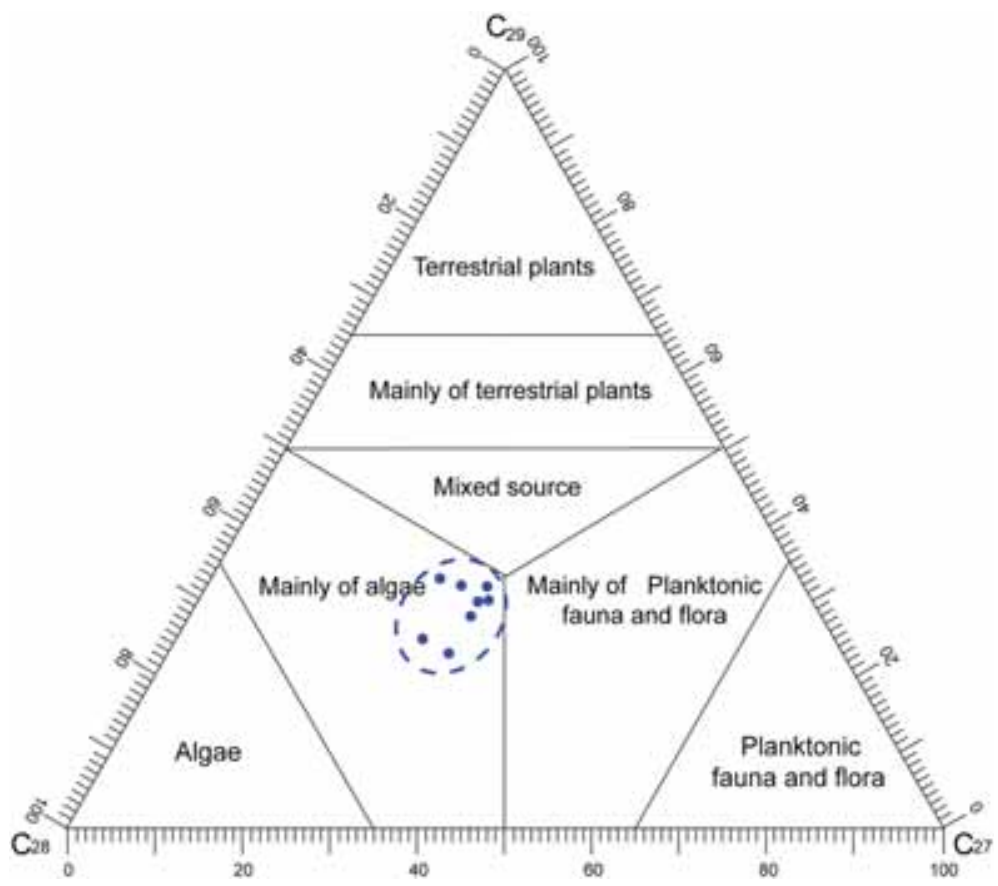

Figure 8. Relative contents of the $\mathrm{C}_{27}, \mathrm{C}_{28}$ and $\mathrm{C}_{29}$ sterane in the samples of UPPMRs and the origin of organic matter.

was also uniform with the result shown by the characteristics of $n$-alkanes in samples. According to the regional dynamic metamorphism research, it was indicated that the UPPMR was derived from the metamorphism of marine strata from neoproterozoic to palaeozoic in the Yangtze craton. So, there might be a chance that the organic matter was generated from the syndeposition of algae in the neoproterozoic to palaeozoic strata via the metamorphism at high temperature and pressure. But the parameters of sterane isomers indicated median maturity, which conflicted with the theory of metamorphism. So, the only reliable explanation was that the organic matter did not experience the ultra-high temperature and pressure of metamorphism. If that actually happened, it is consistent with the evidence of organic maturity indicated by kerogen and bitumen. 


\subsection{Characteristics of kerogen from} No. 11 sample

The only kerogen was extracted from the No. 11 sample using a centrifuge at a low-rotational speed. Based on comparing the FTIR spectrum of kerogen from the No. 11 sample (figure 9), the major functional groups involved are $\mathrm{CH}_{3} \mathrm{CH}_{2}$ and $\mathrm{C}-\mathrm{H}$. The absorption intensity of $\mathrm{CH}_{3} \mathrm{CH}_{2}$ and $\mathrm{C}-\mathrm{H}$ is 0.1163 and 0.1116 , respectively, which is higher than that of the aromatic-CH bond (see $I_{870 \mathrm{~cm}^{-1}}$ and $I_{750 \mathrm{~cm}^{-1}}$ in figure 9). It was indicated that the type of kerogen is prone to type $\mathrm{II}$ or $\mathrm{II}_{1}$, although a little bit of the absorption peak of the oxygen bond appeared at $I_{1720 \mathrm{~cm}^{-1}}$. The origin of incorporated oxygen will be discussed in the paragraph on oxygen isotopes.

Especially, an absorption peak of rutile appeared in the kerogen concentrate. Based on previous research studies ( $\mathrm{Xu}$ et al. 2004), the rutile was the common accessory minerals in the process of metamorphism, whose origin can be divided into two types. One type of rutile was of regular nanometre-size deformed twins, associated with garnet and omphacite, with a modulated texture. It indicated a strong strain effect on rutile crystals, and might be tightly related to the subduction, return and subsequent continental collision. Another type of rutile was included in the garnets or omphacites. The crystal of the latter type was well preserved in the host minerals, and had not undergone crystal distortion during exhumation and subduction. By means of the new Zr-in-rutile geothermometer reported by Zack et al. (2004), the formation temperature of rutile in the epidotic schist of CCSD at a depth of $1841 \mathrm{~m}$ was estimated to be from $690^{\circ} \mathrm{C}$ to $787^{\circ} \mathrm{C}$ (Chen et al. 2005). This was slightly lower than the conclusion from continental dynamics studies. It was very likely that the rutile in the No. 11 sample formed in the inclusions of garnet or omphacite. At the stage of tectonic return, the eclogite suffered from amphibolitefacies retrograde metamorphism, so that formation fluid was quite active. Then the diffusion exchange of ion in the rutile resulted in the formation temperature of the Zr-in-rutile geothermometer being lower than that of the metamorphism peak. So, this evidence indicated that the kerogen associated with the rutile might mature regularly at the stage of retrograde metamorphism.

The $\delta^{18} \mathrm{O}$ value of rocks in the main hole of CCSD from the ground surface to $1700 \mathrm{~m}$ depth was slightly increasing. From the near surface to $1000 \mathrm{~m}$ depth, the $\delta^{18} \mathrm{O}$ value of UPPMR was well below zero. This indicated the shallow rocks had experienced the fluid-rock exchange with atmospheric precipitation. Accompanied by an increase in the depth from 1000 to $1700 \mathrm{~m}$, the $\delta^{18} \mathrm{O}$ value of rocks raised more than zero and increased up to $\delta^{18} \mathrm{O}=2.4 \%$ at a depth of $1660 \mathrm{~m}$. However, it is worth noting that the $\delta^{18} \mathrm{O}$ value of the No. 11 sample at $1842.6 \mathrm{~m}$ suddenly changed to $-10 \%$. The TOC of the No. 11 sample was $1820 \mu \mathrm{g} / \mathrm{g}$ for most of the samples. The variation trend of the oxygen isotope was coupled with TOC, which mutually explains both the oxygen isotope and the organic content (figure 10). The relationship between the TOC and $\delta^{18} \mathrm{O}$ value indicated that the fluid-rock exchange reaction was the main reason for the relative abundant TOC and lowmaturity organic matter detected in the No. 11 samples.

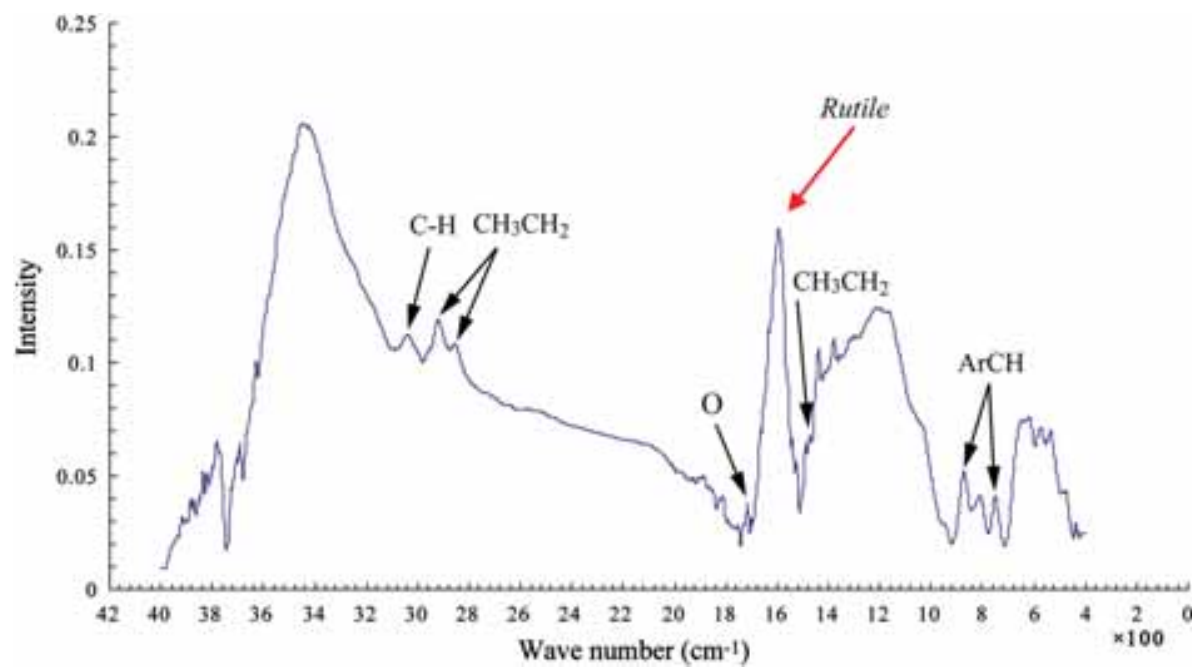

Figure 9. The FTIR spectrum of the kerogen from sample No. 11 (epidote biotite amphibolite). 


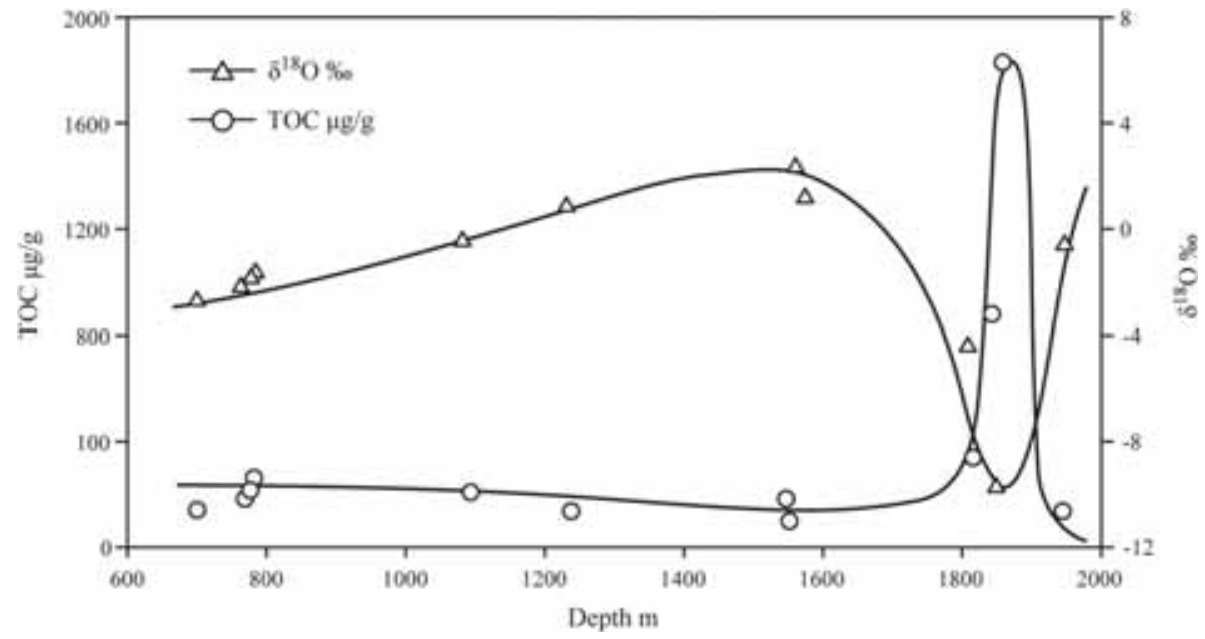

Figure 10. The relationship between TOC and the oxygen isotope of the para-metamorphic rock samples.

The carbon isotope of kerogen separated from the epidote biotite amphibolite was detected at $\delta^{13} \mathrm{C}=-31.4 \%$. In a previous research, the inclusions of $\mathrm{N}_{2}-\mathrm{CH}_{4}$ in the eclogite were first discovered by Fan et al. (2005). Based on the petrography study of $\mathrm{N}_{2}-\mathrm{CH}_{4}$ inclusions, these pure gaseous inclusions were mostly primary and mainly exhibited as isolated and little groups in banded quartz veins in the eclogite, associated with the salt-water inclusions of high-medium salinity. It was implied that the $\mathrm{N}_{2}-\mathrm{CH}_{4}$ inclusions were probably captured in HP-UHP metamorphism. The $\delta^{13} \mathrm{C}$ value of $\mathrm{CO}_{2}$ in the salt-water inclusions was from $-32 \%$ to $-28 \%$, close to the $\delta^{13} \mathrm{C}$ of the organic matter deposited in marine sediments (Mook 2001). Therefore, the origin of carbon from the inclusions captured in the HP-UHP metamorphism might be the organic origin, and not disturbed by the effect of the mantle fluid. It could also be implied that the protogenetic organic matter was probably cracked into $\mathrm{CH}_{4}$ and $\mathrm{CO}_{2}$ at ultrahigh pressure and temperature, with the rapid subduction in <10 My. But no fluidic hydrocarbon inclusions had been discovered so far. Therefore, the primary record of hydrocarbons is unfortunately deficient.

\subsection{Maceral characteristics of UPPMRs}

The maceral observation in the oil-immersed reflection was the direct evidence for the origin of the organic matter in the UPPMR. The main maceral in samples was the mineral-bituminous matrix, as shown in figure 11. This kind of maceral was formed by the condensation of organic matter associated with minerals (Carr 1999). Based on the

\begin{tabular}{|c|c|c|}
\hline \multirow[b]{2}{*}{$\begin{array}{l}\text { Number of } \\
\text { Sample }\end{array}$} & \multicolumn{2}{|c|}{ Reflectivity } \\
\hline & minerals & $\begin{array}{c}\text { Organic } \\
\text { matter }\end{array}$ \\
\hline \multirow{3}{*}{ No.1 } & & 0.14 \\
\hline & & 0.13 \\
\hline & & 0.28 \\
\hline No. 3 & 0.6 & 0.3 \\
\hline \multirow{3}{*}{ No. 4} & 0.4 & 0.1 \\
\hline & 0.6 & 0.2 \\
\hline & 0.5 & 0.2 \\
\hline No. 5 & 0.5 & 0.3 \\
\hline No.6 & 0.4 & 0.3 \\
\hline \multirow{2}{*}{ No. 8} & 0.7 & 0.3 \\
\hline & 0.5 & 0.2 \\
\hline No. 10 & 1.2 & 0.3 \\
\hline \multirow{4}{*}{ Not1 } & 2.6 & 0.4 \\
\hline & 1,1 & 0.3 \\
\hline & 1.3 & 0.4 \\
\hline & 0.8 & 0.4 \\
\hline No. 12 & 0.4 & 0.1 \\
\hline
\end{tabular}

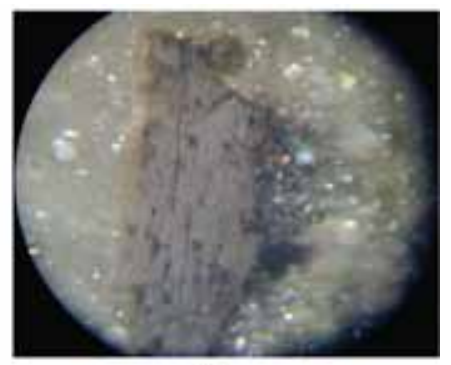

(a)

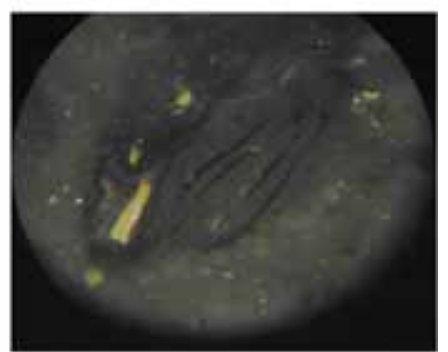

(b)

Figure 11. The detected reflectivity of organic matter and mineral in the samples of UPPMRs with oil-immersed reflection. (a) Bitumen in sample No. 1 (B387R304P1a), $\times 240$ and (b) bitumen and unidentified mineral in No. 5 (B623R439P6a), ×240.

morphology of maceral, the origin of the mineral-bituminous matrix might be a degraded or algae amorphous mass (Huang et al. 2003; Rao et al. 2006a, b; Wang et al. 2006). The reflectivity of the organic matter was $0.1-0.4 \%$, implying that the organic matter was at the immature stage. Meanwhile, the reflectivity of the mineral was $0.4-2.6 \%$, which was much lower than that of normal minerals. The reflectivity of the calcite in sample No. 11 (B957R627P4t) was 2.6\%, which indicated that the calcite did not experience 
the metamorphism of ultrahigh pressure and temperature. So, in other words, this mineralbituminous groundmass was of secondary origin. It is inferred that the mineral-bituminous matrix might be carried in stratum by the activity of the formation fluid during the return of subduction accompanied by retrograded metamorphic minerals. Moreover, the results of Rock-Eval also revealed that the organic matter in the UPPMR was mainly trapped at the stage of subduction return, because the $\mathrm{S}_{1} / \mathrm{TOC}$ of most samples was $>50 \%$. It was illustrated that the majority of the organic matter in the UPPMR was absorbed on the surface of the minerals.

\section{Conclusions}

(a) With the GC-MS analysis of the soluble organic matter from 12 samples, the marine origin of the organic matter and the anoxic sedimentary setting were observed. Referring to the bimodal chromatography of $n$-alkanes and the triangular chart of $\mathrm{C}_{27}, \mathrm{C}_{28}$ and $\mathrm{C}_{29}$ sterane, the source of the organic matter was confirmed as mainly algae, likely marine plankton. With regard to maturity, the steranes could be detected in most of the samples, and the distribution range of $\mathrm{C}_{29}$ sterane $20 \mathrm{~S} /(20 \mathrm{~S}+20 \mathrm{R})$ was from 0.41 to 0.63 and the value of $\mathrm{C}_{29}$ sterane $\beta \beta /(\alpha \alpha+\beta \beta)$ was $0.31-0.44$. Both of the maturity parameters reflected the same level of maturity as the parameters of hopanes $\left(R_{\mathrm{o}}=0.6-0.9 \%\right)$ which conflicted with the theory of metamorphism. So, the only reliable explanation was that the organic matter was from the active formation fluid during the process of subduction return and retrograde metamorphism.

(b) In addition, the absorption peak of rutile appeared in the kerogen of sample No. 11 (B957R627P4t). Since the retrograde metamorphism of amphibolite-facies, the diffusion exchange of the ion in the rutile resulted in the metamorphism temperature of the $\mathrm{Zr}$ in-rutile geothermometer being lower than that of the metamorphism peak. It was also indicated that the $\delta^{18} \mathrm{O}$ value of the No. 11 sample at $1842.6 \mathrm{~m}$ suddenly reduced up to $-10 \%$. The corresponding TOC of the No. 11 sample was $1820 \mu \mathrm{g} / \mathrm{g}$, which is the highest of all samples. The relationship between the TOC and $\delta^{18} \mathrm{O}$ value indicated that the fluid-rock exchange reaction was the main reason why the relative abundant TOC and low-maturity organic matter had been detected in the No. 11 sample. This sample (No. 11) is located near the shear zone, which was activated during the process of subduction return. The rock type of sample No. 11 is epidote amphibolite facies, which is a product of low-grade metamorphism. Thus, it could be inferred that the retrograde metamorphism resulted in the fluid-rock exchange at the returning stage of metamorphism.

(c) The main maceral in the samples was the mineral-bituminous matrix, which was the source of the origin of the degraded or algae amorphous mass. The reflectivity of the organic matter and the mineral in the samples of UPPMR were much lower than the maturity of the organic matter and normal minerals, respectively. So, it was indicated that the calcite associated with mineral-bituminous groundmass did not experience the metamorphism of ultrahigh pressure and temperature. Moreover, the results of Rock-Eval also revealed that the organic matter in the UPPMR was mainly trapped at the stage of subduction return, because the $\mathrm{S}_{1} /$ TOC of most samples was $>50 \%$. It was illustrated that the majority of organic matter in the UPPMR was absorbed on the surface of the minerals. The $\delta^{13} \mathrm{C}$ of $\mathrm{CO}_{2}$ in the salt-water inclusions was from $-28 \%$ to $-32 \%$, close to the $\delta^{13} \mathrm{C}$ of the organic matter deposited in marine sediments. It was implied that the protogenetic organic matter was probably cracked into $\mathrm{CH}_{4}$ and $\mathrm{CO}_{2}$ at ultrahigh pressure and temperature, with the rapid subduction in $<10 \mathrm{My}$. Then, the subduction return and retrograde metamorphism resulted in the dramatic activity of the formation fluid.

\section{Acknowledgements}

This study was funded by the Strategic Priority Research Program of the Chinese Academy of Sciences (XDA14010101) and the projection of Chinese Continental Scientific Drilling (CCSD). The extraction, separation, GC and GC-MS analyses were performed at the National Research Centre of Geoanalysis. The Rock-Eval was conducted in the Key Laboratory of Petroleum Geology (KLPG), PetroChina. The observation of maceral was completed in China University of Mining \& Technology, Beijing. We are extremely 
grateful for the rock samples supplied by Chinese Academy of Geological Science.

\section{References}

Carr A D 1999 A vitrinite reflectance kinetic model incorporating over-pressure retardation; Mar. Pet. Geol. 16 355-377.

Carswell D A and Compagnoni R 2003 Ultra-high pressure metamorphism; Eur. Mineral. Union Notes Mineral 5 1-508.

Chen J, Xu Z Q and Li X P 2005 The formation of nanometer twins of rutile and its textural characteristics in UHP eclogite; Acta Petrol. Sin. 21 399-404.

Chen R X, Zheng Y F, Gong B, Zhao Z F, Gao T S, Chen B and Wu Y B 2009 Origin of retrograde fluid in ultrahigh-pressure metamorphic rocks: Constraints from mineral hydrogen isotope and water content changes in eclogite-gneiss transitions in the Sulu orogen; Geochim. Cosmochim. Acta 71 2299-2325.

Chopin C 2003 Ultrahigh-pressure metamorphism: Tracing continental crust into the mantle; Earth Planet. Sci. Lett. 212 1-14.

Clegg H, Wilkes H, Oldenburg T, Santamaría-Orozco D and Horsfield B 1998 Influence of maturity on carbazole and benzocarbazole distributions in crude oils and source rocks from the Sonda de Campeche, Gulf of Mexico; Org. Geochem. 29(1-3) 183-194.

Coleman R G and Wang X M 1995 Ultrahigh pressure metamorphism; Cambridge University Press, Cambridge, pp. 276-281.

Cui J W, Wang L J, Li P W, Tang Z M and Sun D S 2009 Wellbore breakouts of the main borehole of Chinese continental scientific drilling (CCSD) and determination of the present tectonic stress state; Tectonophys. $\mathbf{4 7 5}(\mathbf{2})$ 220-225.

Durand B 1980 Kerogen, insoluble organic matter from sedimentary rocks; Technip, Paris.

Fan H R, Guo J H, Hu F F, Chu X L and Jin C W 2005 Fluid inclusions and exhumation history of ultra-high pressure metamorphic rocks, at Lanshantou in the Sulu terrane, southeastern Shandong Province; Acta Petrol. Sin. 21 1125-1132.

Hacker B R and Liou J G 1998 When continents collide: Geodynamics and geochemistry of ultrahigh-pressure rocks; Kluwer Academic Publishers, Dordrecht, pp. 1-323.

Huang D F, Zhang D J, Wang P R, Zhang L Y and Wang T G 2003 Genetic mechanism and accumulation condition of immature oil in China; Petroleum Industry Press in China (in Chinese), Beijing, pp. 1-56.

Li J G 2002 Unusual distribution and its origin of $n$-alkanes in extracts of marine carbonate rocks with high maturity and over maturity; Pet. Explor. Dev. 29(4) 8-11.

Liou J G, Tsujimori T, Zhang R Y, Katayama I and Maruyama S 2004 Global UHP metamorphism and continent subduction/collision: The Himalayan model; Int. Geol. Rev. 46127.

Liu F L, Axel G, Zeng L S and Xue H M 2008 SHRIMP U-Pb dating, trace elements and the $\mathrm{Lu}-\mathrm{Hf}$ isotope system of coesite-bearing zircon from amphibolite in the SW Sulu UHP terrane, eastern China; Geochim. Cosmochim. Acta 72 2973-3000.
Liu F L, Wang F and Liu P H 2009a Genetic relationship between pegmatite formation and anatexis of ultrahigh pressure (UHP) metamorphic rocks in the Weihai area, North Sulu UHP Terrane; Acta Geol. Sin. 83 1687-1702 (in Chinese).

Liu S W, Li Q G, Liu C H, Lü Y J and Zhang F 2009b Guandishan Granitoids of the Paleoproterozoic Lüliang Metamorphic Complex in the Trans-North China Orogen: SHRIMP Zircon Ages, petrogenesis and tectonic implications; Acta Geol. Sin. (Engl.). 83 580-602.

Liu Y C, Gu X F and Li S G 2009c Rapid exhumation and slow cooling of ultrahigh-pressure eclogite in the North Dabie complex zone, central China; Acta Petrol. Sin. 25 2149-2156.

Lou Y X, Wei C J, Chu H, Wang W and Zhang J S 2009 Metamorphic evolution of high-pressure eclogite from Hong'an, Weatern Dabie Orogen, central China: Evidence from petrography and calculated phase equilibria in system $\mathrm{Na}_{2} \mathrm{O}-\mathrm{CaO}-\mathrm{K}_{2} \mathrm{O}-\mathrm{FeO}-\mathrm{MgO}-\mathrm{Al}_{2} \mathrm{O}_{3}-\mathrm{SiO}_{2}-\mathrm{H}_{2} \mathrm{O}-\mathrm{O}\left(\mathrm{Fe}_{2} \mathrm{O}_{3}\right)$; Acta Petrol. Sin. 25 124-138.

Moldowan J M, Sundararaman P and Schoell M 1986 Sensitivity of biomarker properties to depositional environment and/or source input in the Lower Toarcian of S. W. Germany; Org. Geochem. 10 915-926.

Mook W G 2001 Abundance and fractionation of stable isotopes; In: Environmental isotopes in the hydrological cycle. Principles and application; Vol. 1, UNESCO/IAEA, Paris, pp. 31-48.

Peters K E, Kontorovich A E, Huizinga B J, Moldowan J M and Lee C Y 1994 Multiple oil families in the west Siberian Basin; AAPG Bull. 78 893-909.

Price L C and Wenger L M 1992 The influence of pressure on petroleum generation and maturation as suggested by aqueous pyrolysis; Org. Geochem. 19(1) 141-159.

Rao Z, Luo L Q, Fang J H, Zhan X C, Yang L and Su J 2006a Organic matter be detected and its genic origin be studied for ultrahigh-pressure metamorphic rock from the 0-2000 m main hole of the Chinese continental scientific drilling project; Acta Petrol. Sin. 22 2060-2066.

Rao Z, Yang L, Luo L Q, Zhan X C and Fang J H 2006b The extraction of soluble organic matter in UHP metamorphic rock from main drill hole of the Chinese continental scientific drilling project; Acta Petrol. Mineral. 25 257-260.

Richard D P, Joanna M C, Gordon D L, Athina C, Ioanna B and Colin E S 2008 Kerogen-bound glycerol dialkyl tetraether lipids released by hydropyrolysis of marine sediments: A bias against incorporation of sedimentary organisms? Org. Geochem. 39 1359-1371.

Schneider A, Mantzaras J and Jansohn P 2006 Experimental and numerical investigation of the catalytic partial oxidation of $\mathrm{CH}_{4} / \mathrm{O}_{2}$ mixtures diluted with $\mathrm{H}_{2} \mathrm{O}$ and $\mathrm{CO}_{2}$ in a short contact time reactor; Chem. Eng. Sci. 61(14) 4634-4649.

Smith D C 1984 Coesite in clinopyroxene in the Caledonides and its implications for geodynamics; Nature 310 641-644.

Tissot B P and Welte D H 1984 Petroleum formation and occurrence; Springer, New York.

Wang Y P, Zhang S C, Wang F Y, Wang Z Y, Zhao C Y, Wang H J, Liu J Z, Lu J L, Geng A S and Liu D H 2006 Thermal cracking history by laboratory kinetic simulation of Paleozoic oil in eastern Tarim Basin, NW China, implications for the occurrence of residual oil reservoirs; Org. Geochem. 37 1803-1815. 
Wang C Y, Du J G, Yi D, Zhou X C and Chen Z 2008 Experiment study on terpane under high pressure and temperature; J. Mineral. Petrol. 28 76-80.

Xu J, Chen Y C, Wang D H, Yu J J, Li C J, Fu X J and Chen Z Y 2004 Titanium mineralization in the ultrahigh-pressure metamorphic rocks from Chinese continental scientific drilling 100-2000 m main hole; Acta Petrol. Sin. 20 $119-126$.

Xu Z Q, Zeng L S, Liu F L, Yang J S and Zhang Z M 2006 Polyphase subduction and exhumation of the Sulu highpressure-ultrahigh-pressure metamorphic terrane; Geol. Soc. Am. Spec. Paper 403 93-113.

Zeng L S, Liang F H, Chen Z Y, Liu F L and Xu Z Q 2009 Metamorphic garnet pyroxenite from the 540-600 m main borehole of the Chinese continental scientific drilling (CCSD) project; Tectonophys. 475(2) 396-412.

Zhang S C and Huang H P 2005 Geochemistry of Palaeozoic marine petroleum from the Tarim Basin, NW China: Part 1. Oil family classification; Org. Geochem. 36 1204-1214.
Zhang Z M, Shen K, Sun W D, Liu Y S, Liou J G, Cao Shi C and Wang J L 2008 Fluids in deeply subducted continental crust: Petrology, mineral chemistry and fluid inclusion of UHP metamorphic veins from the Sulu orogen, eastern China; Geochim. Cosmochim. Acta 72 3200-3228.

Zheng Y F 2008 A perspective view on ultrahigh-pressure metamorphism and continental collision in the Dabie-Sulu orogenic belt; Chinese Sci. Bull. 53 3081-3104.

Zheng Y F, Chen R X and Zhao Z F 2008 Chemical geodynamics of continental subduction-zone metamorphism: Insights from studies of the Chinese continental scientific drilling (CCSD) core samples; Tectonophys. 475(2) 327-358.

Zhu M Q 1981 Studies on the combinative form of kerogen with pyrite and the separation of $\mathrm{FeSO}_{4}$ and $\mathrm{Fe}_{2}\left(\mathrm{SO}_{4}\right)_{3}$; Pet. Geol. Exp. 3(4) 299-306 (in Chinese).

Zack T, Moraes R and Kronz A 2004 Temperature dependence of $\mathrm{Zr}$ in rutile: Empirical calibration of a rutile thermometer; Contrib. Mineral. Petrol. 148(4) 471-488.

Corresponding editor: N V ChALAPATHI RAO 